(C) Copyright by Wydawnictwa Naukowe Instytutu Lotnictwa

\title{
MI-2 HELICOPTERS USED WITHIN THE STRUCTURES OF THE AVIATION DETACHMENT OF THE MINISTRY OF INTERIOR
}

\author{
Robert Konieczka \\ Chair of Aviation Technologies, Transportation Department of the Silesian University of Technology, \\ ul. Krasińskiego 8, 40-019 Katowice \\ robert.konieczka@polsl.pl
}

Abstract

In the article, the author presents the wide-scale use of Mi-2 helicopters in the different entities subordinated to the Minister of Interior - from the introduction of the design, until the present. Insights are presented pertaining to the early stages of the helicopter's service life within the structures of the $103^{\text {rd }}$ NJW MSW Aviation Regiment in the 1960s. The article describes selected aspects related to the introduction of the design, training, operational use and problems encountered. The service life of Mi-2 helicopters operating within the structures of the Ministry of Interior ended upon liquidation of the Ministry's Aviation Detachment. That is when another chapter in the history of the helicopters was started, this time operated within the structures of the Police and Border Guard forces, where their service life has not been fully used up until this day. The paper describes the reality of every-day use to perform specific tasks, presents the location of aerodromes, touches upon a shift in the philosophy behind the use of the helicopters, and describes their strong and weak points. The PZL-Kania helicopter has been also presented, being a modernized version of the Mi-2, and still used in Poland within the aviation forces of the Ministry of Interior and Administration.

Keywords: Ministry of Interior and Administration, Mi-2 helicopter, public safety, Nadwiślańskie Jednostki Wojskowe, Border Guard, Police

\section{$103^{\text {RD }}$ AVIATION REGIMENT AS THE PRIMARY POST-WAR AVIATION FORMATION OF THE MINISTRY OF INTERIOR}

The aviation structures of the Ministry of Interior were established long before taking delivery of the first Mi-2 helicopters, and have been operating since World War II. That is when by means of organizational order No. 001 dated 1 April 1944, the 103 ${ }^{\text {rd }}$ Independent Aviation Communications Squadron was incorporated in the 1st Polish Army. Its task was to maintain communications between the commanders and the units they were subordinated to. The unit was performing its duties relying 
on 10 Po-2 aircraft and less than 100 soldiers. The unit followed the battle route from Trojanów near Żytomierz, all the way to Rhinow near Berlin, setting up its temporary bases on the airfields in Gończy Bród, Zaglinki, Milejów, Dębowka, Żyrzyn, Rębków and Soplicowo. The last of those airfields was used to launch missions over the uprising-engulfed Warsaw. Initially, these were reconnaissance, and then supply flights. These flights have failed, however, to bring about any combat-related results during the uprising. Then the unit proceeded to Błonie, Sanniki, Brześć Kujawski, Więćbork, Sępolno, Złotów, Jastrów and Sweden. Its subsequent airfields constituted a part of the Pommernstellung: Świdwin, Gryfice, Narost, Gozdowice. During the Berlin operation, the unit was flying, inter alia, medical evacuation missions.

Following the end of the war, on 13 July 1945, the unit was relocated to Katowice. On 20 October of the same year, the squadron was liquidated, and replaced by the 9th Independent Liaison Aviation Squadron (according to other sources, the Independent Interior Security Corps Communications Squadron). Just a few days later, the squadron relocated to the airfield on the Warsaw's district of Mokotów. In October 1946 the squadron's equipment was supplemented with Messerschmitt Bf. 108 typhoon aircraft. By means of the order of 7 August 1946, its name was changed to the Independent, Special Purpose Aviation Communications Squadron. From 1948 onwards, the squadron was based at the Bielany airfield. At that time, the unit was responsible, inter alia, for securing a national referendum and the Vistula campaign could be conducted without disruptions. Between 1953 and 1955, the unit was using the following aircraft types: Po-2, CSS-13, Fi 156, FW.58 and An-2, introduced in 1955. On 20 February 1956, the squadron's name was changed into the Independent Aviation Communications Squadron of the Committee of Internal Security. 1958 saw delivery of the first SM-1 helicopter serving in the Squadron.

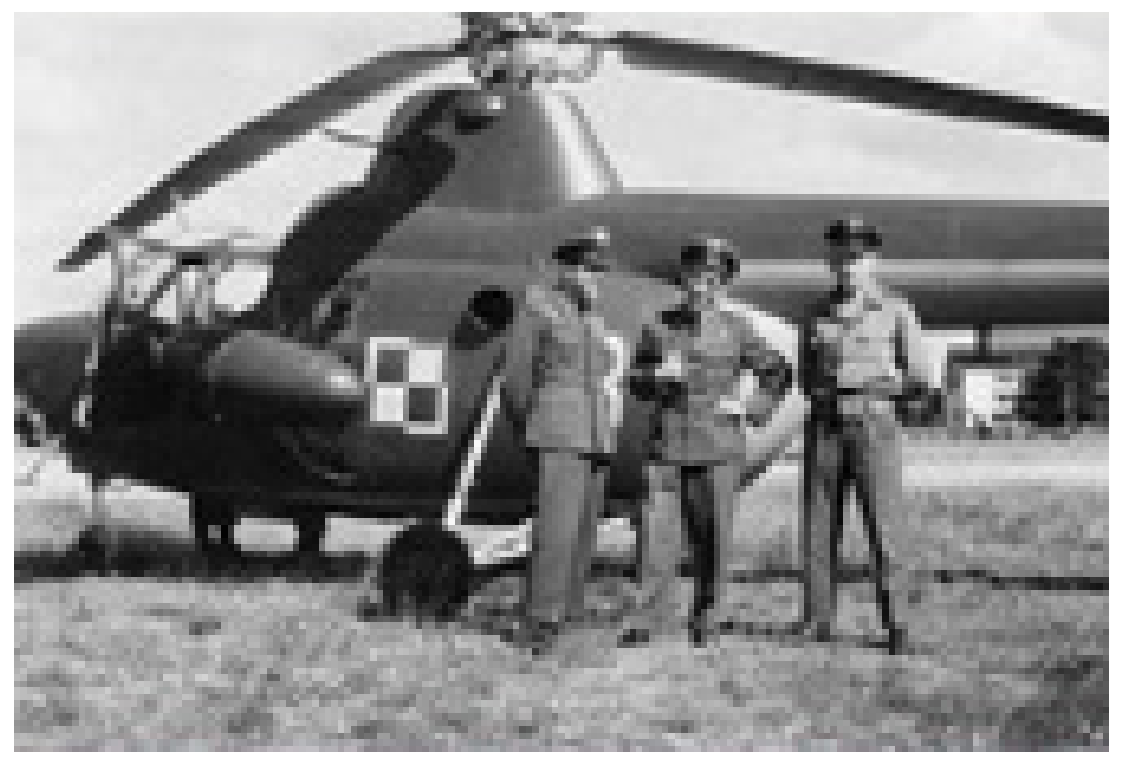

Fig. 1: Personnel of the Independent, Special Purpose Aviation Communications Squadron against the background of the unit's first SM-1 helicopter ${ }^{1}$.

1 Leaflet - 103 Pułk Lotnictwa Nadwiślańskich Jednostek Wojskowych Ministerstwa Spraw Wewnętrznych. 70 lat. 1.04.2014. 
Just a year later, the squadron took delivery of the first Mi-4 helicopters, and in 1965, SM-2 helicopters were introduced. On 15 October of that same year the name was changed into the Independent Aviation Transport and Communications Squadron of the Ministry of Interior, subordinated to the commander of Nadwiślańska Brigade of the Ministry of Interior. On 6 September 1968 another cosmetic change of the name took place - this time it evolved into the Independent Aviation Transport and Communications Squadron of the Nadwiślańska Brigade of the Ministry of Interior. Finally, on 5 June 1974, a real qualitative change took place, where the Brigade was transformed into the 103rd Aviation Regiment of the Nadwiślańska Brigade of the Ministry of Interior. From 9 January 1975 the name of 103 Pułk Lotnictwa Nadwiślańskich Jednostek Wojskowych MSW (103 pl NJW MSW) has been used $[1,2]$.

\section{FIRST MI-2 HELICOPTERS FOR THE 103RD INDEPENDENT AVIATION TRANSPORT AND COMMUNICATIONS SQUADRON OF THE MINISTRY OF INTERIOR}

The first Mi-2 helicopters for the 103rd Independent Aviation Transport and Communications Squadron of the Ministry of Interior were delivered on 2 March 1968. They were bound to replace the SM-1 and SM-2 helicopters that were nearing the end of their service life. The new generation rotorcraft were powered, unlike their predecessors, by turbojet engines. Prior to their entry into service, an intensive training campaign was conducted at the 47 th Aviation Regiment of Communications and Medical Transport in Modlin. The group of pilots and mechanics trained was headed by the then-commander of the Independent Squadron, flight lieutenant colonel Bolesław Balwirczak. In the summer of the same year, Mi-2 helicopters took part in fire patrolling flights in Białostockie and Kieleckie voivodships [1].
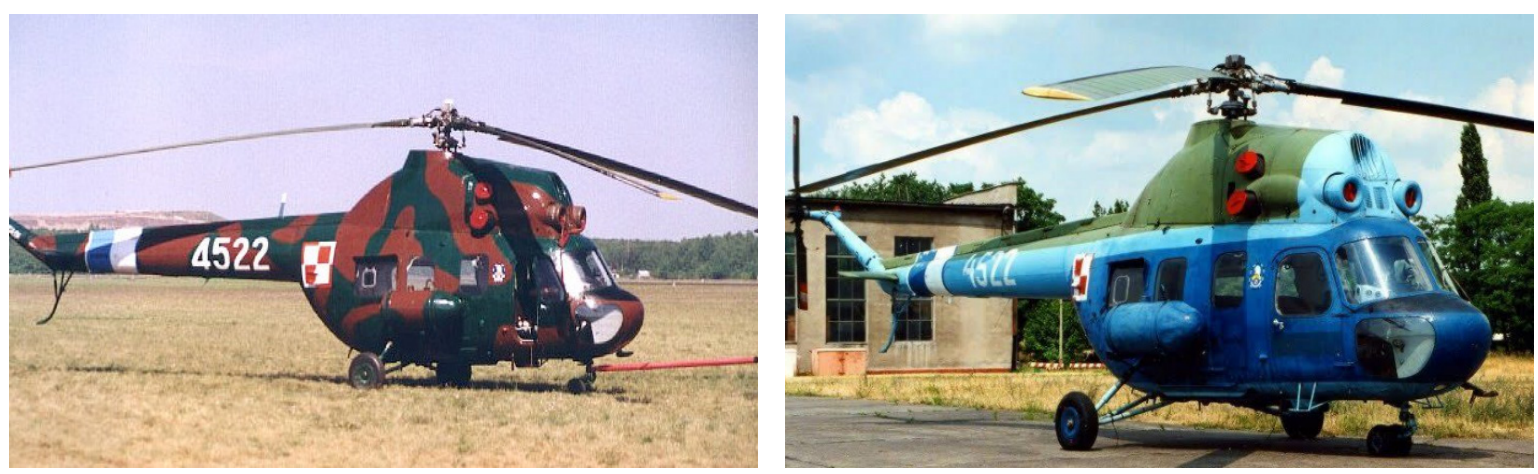

Fig. 2: Different liveries of Mi-2 helicopters from 103 PL NJW MSW, http://samolotypolskie.blogspot.com/2013/02/lotnictwo-policyjne.html

\section{MI-2 OPERATIONS WITHIN THE STRUCTURES OF 103 PL NJW MSW}

Due to their inherent characteristics, $\mathrm{Mi}-2$ helicopters were suitable for performing a wide range of tasks that depended on the current public safety threats and on the needs of the Ministry of Interior. These tasks included the following: 
- passenger transport, performed to the order of the Ministry of Interior,

- transporting VIPs,

- patrolling roads,

- patrolling water bodies,

- transporting special mail,

- detecting fires and directing firefighting units to the sources of fire,

- agricultural flights in the Bieszczady mountain range,

- photogrammetric flights,

- flights performed to secure mass events, such as cycling races (preparation of routes and aerial filming),

- patrol and reconnaissance flights during visits of the Pope and other important foreign delegations,

- flights performed to the order of militia (police) voivodship headquarters, to maintain public order and protect state borders [3].

In order to perform the tasks referred to above, Mi-2 helicopters were equipped with different systems. For instance, to perform agricultural flights and spray pesticides, they were equipped with special tanks and spraying fixtures (Fig. 4). Equipment required for aerial filming and photographing is an interesting solution too. The right-hand side sliding door of the helicopter was adapted in the manner seen in Figure 3, so the images could be shot straight down, in a vertical position, during the flight.

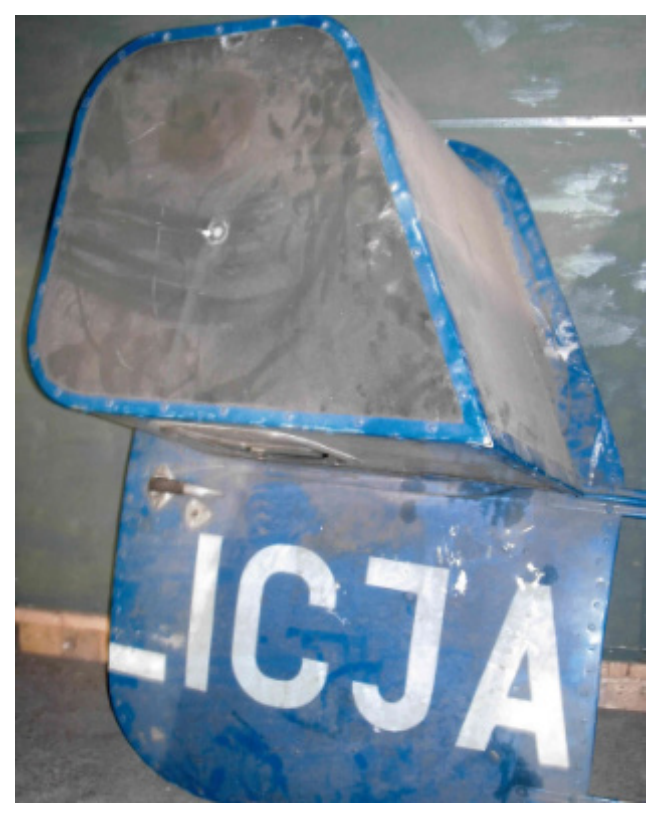

Fig. 3: Right-hand door of the Mi-2 helicopter enabling aerial images to be taken in a vertical position. Walenty Tieśluk's file.

The peculiar equipment of this particular aircraft is presented in figure 5. In this variant, the helicopter was used to counteract illegal demonstrations. It was equipped with ŁGWŁ-300 teargas grenade launchers positioned under the fuselage, and with Preston $600 \mathrm{~W}$ speakers enabling public announcements to be made. The equipment was operated by an operator seating in the passenger cabin, and 
by the pilot, who was using a mirror located under the helicopter's front-lower window. The RO-78 floodlight, positioned behind the main landing gear, in the right-rear section of the fuselage, was an interesting solution too. The floodlight was operated manually, with the use of a grip protruding through the removed glazing of the rear window.

Unfortunately, several accidents have taken place during the service of $\mathrm{Mi}-2$ helicopters in 103 PL NJW MSW. The most tragic of them occurred on 12 November 1985, when the crew made up of flight cpt. Romuald Kędra and second lieutenant Mirosław Karpiński was performing a training cruise flight. Due to deteriorating weather conditions, the helicopter crashed in a forest in the vicinity of the Masurian village of Piecki. Both pilots were killed in the event.

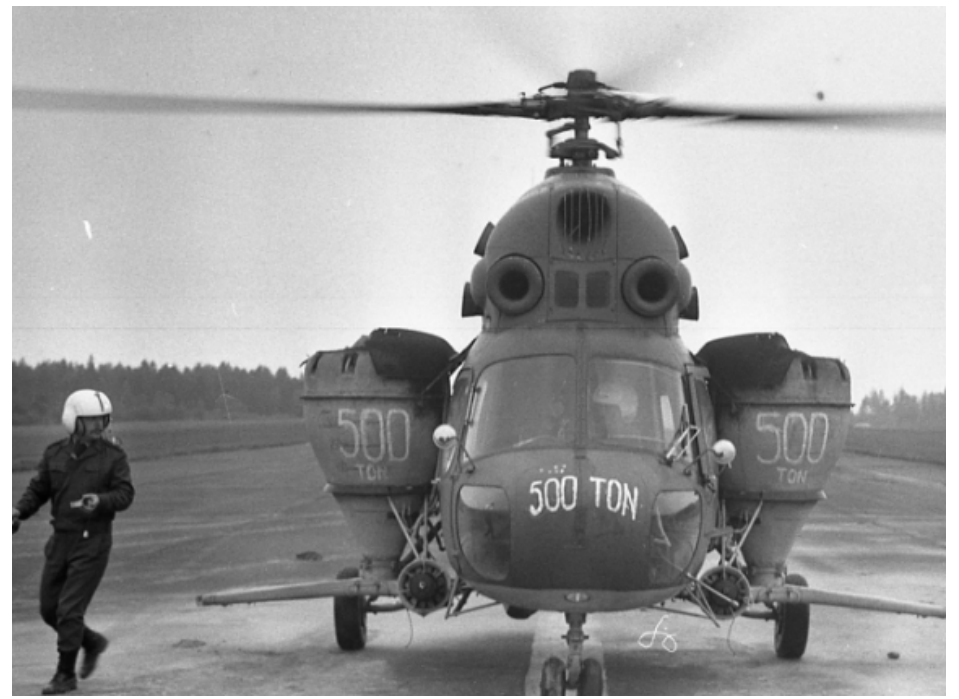

Fig. 4: Agricultural equipment of a military Mi-2 helicopter. Jan Piotr Urbaniak’s file.

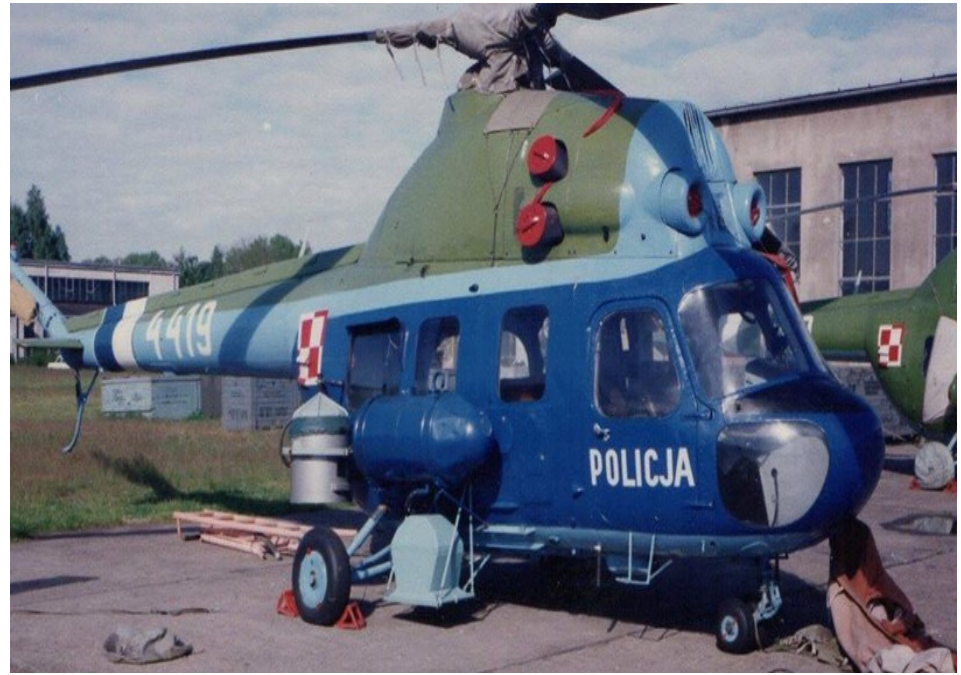

Fig. 5a: Special equipment of the helicopter (described in the article). Marek Dominiak's file. 

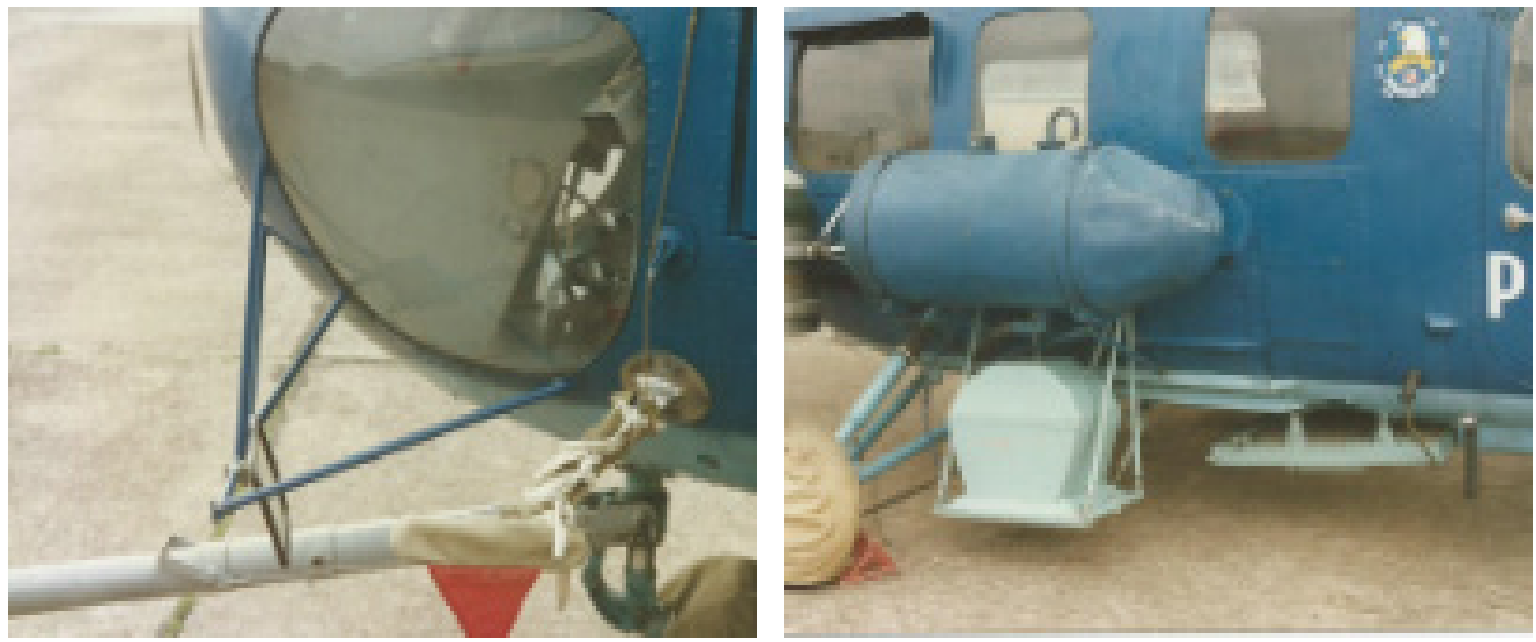

Fig. 5b: Special equipment: left - pilot's mirror; right - speaker and grenade launcher under the airframe. Marek Dominiak's file.

\section{BORDER GUARD'S AVIATION DETACHMENT}

Prior to the establishment of the Border Guard (and of its Aviation Detachment at a later phase), all aviation tasks performed for the benefit of the Ministry of Interior were the responsibility of the 103rd Aviation Regiment of Nadwiślańskie Military Units of the Ministry of Interior and Administration (103 pl NJ MSWiA). The individual organizational units of the Ministry were assigned with a specific number of flight hours they had at their disposal over a given year.

The limits assigned to the Border Patrol Force, later transformed into the Border Guard, were extremely low and sufficed only to get the air crews acquainted with border-zone landing sites that could be potentially used when required. The Border Guard officers were also becoming familiar with the specific nature of missions performed with the use of helicopters. Single transport missions were performed as well (e.g. transporting high-ranking officials of the formation). Prevention-related missions were performed very rarely as well.

The greatest intensity of those efforts dates back to 1992/93, when crews of two helicopters were on duty ("Tobur" campaign) at the Biała Podlaska airport (medium-sized Mi-8 or Mi-17 and light Bell-206 or Mi-2). The crews were reacting on alarms raised by individual Border Guard posts.

The intensity of tasks performed by $103 \mathrm{pl} \mathrm{NJW} \mathrm{MSW} \mathrm{in} \mathrm{the} \mathrm{border} \mathrm{zone} \mathrm{increased} \mathrm{again} \mathrm{in} 1996$ and 1997. That is when a light helicopter (Mi-2 or Bell-206) was on stand-by at the Krywlany airfield. This was required due to an increased number of illegal flights performed by aircraft from the other side of Poland's eastern border, smuggling people or goods. The main task of the helicopters was to detect and follows such illegal flights crossing the border [2].

In the fall of 1994 Poland received financial subsidies from Germany and earmarked the funds to modernize and expand its border protection systems, thus enhancing the level of its internal security. In consideration of the above, a contract was signed with WSK PZL "Świdnik" at the end of 1994, requiring that two PZL Kania helicopters be delivered, along with the additional equipment specified, by mid-1995. In order to ensure that the individual types of forces could communicate with each other, helicopters used by the Police and by the Border Guard (two per formation) were equipped with the 
same radio systems. In addition, one of the then most modern FLIR 4000 observation systems, SX-5 floodlights and on-board winches were fitted as well [4].

The first official move towards establishment of the Border Guard Aviation Detachment has the form of Disposition No. 20 of the National Border Guard Commander dated 29 April 1995. The said Disposition established the organizational structure of the Border Guard Aviation Detachment [5]. Pursuant thereto, the detachment was subordinated to the Director of the National Border Protection Department in the National Border Guard Headquarters. At the same time, a decision was taken to assign two newly acquired helicopters to the Podlaski Branch of the Border Guard, which was responsible for the section of the national border at which the largest number of incidents was recorded. As a result, an aviation department was established in Białystok.

In 1998, the contract for the purchase of five PZL-104M WILGA 2000 aircraft was due to materialize. The said contract envisaged that the machines would be supplied successively, starting in late spring of 1998. However, delays attributable to the manufacturer have resulted in the delivery of the last aircraft being postponed until early 1999.

The aviation department of the Podlaski Branch of the Border Guard was expanded to include four independent aviation sections equipped with the aircraft mentioned above. They were based at the following airfields:

1. Warmińsko - Mazurskim Branch of the Border Guard - Kętrzyn-Wilamowo airfield;

2. Nadbużański Branch of the Border Guard - Lublin Radawiec airfield;

3. Bieszczadzki Branch of the Border Guard - Rzeszów Jasionka airfield;

4. Lubuski Branch of the Border Guard - Zielona Góra-Przylep airfield [6,7].

2000 was a breakthrough year for the Border Guard's Aviation Detachment. The aviation and marine technology section operating within the National Border Guard Headquarters was liquidated in May. It was replaced by the Aviation and Marine Technology Section, forming part of the Technology and Procurement Office of the National Border Guard Headquarters, and acted as an independent organizational unit tasked with managing and supervising the aviation operations. The section was subordinated directly to the Director of the Aviation and Marine Technology Office of the National Border Guard Headquarters.

\section{CQUISITION OF MI-2 HELICOPTERS TO OPERATE WITHIN THE BORDER ZONE}

By means of the decision of the Minister of Interior and Administration No. 69 dated 15 March 2000, Nadwiślańskie Military Units of the Ministry of Interior and Administration were liquidated. Hence, the $103 \mathrm{pl}$ NJW MSWiA, as mentioned above, ceased to exist as well. Some of its aircraft (primarily medium-sized $\mathrm{Mi}-8$ and $\mathrm{Mi}-17$ helicopters) were transferred to the aviation forces of the Ministry of National Defense. The remaining aircraft were taken over by the Police and Border Guard aviation detachments/

Pursuant to mutual arrangements, the Border Guard acquired the following aircraft:

- four Mi-2 helicopters,

- one W-3 Sokół helicopter,

- one M-20 MEWA airplane. 


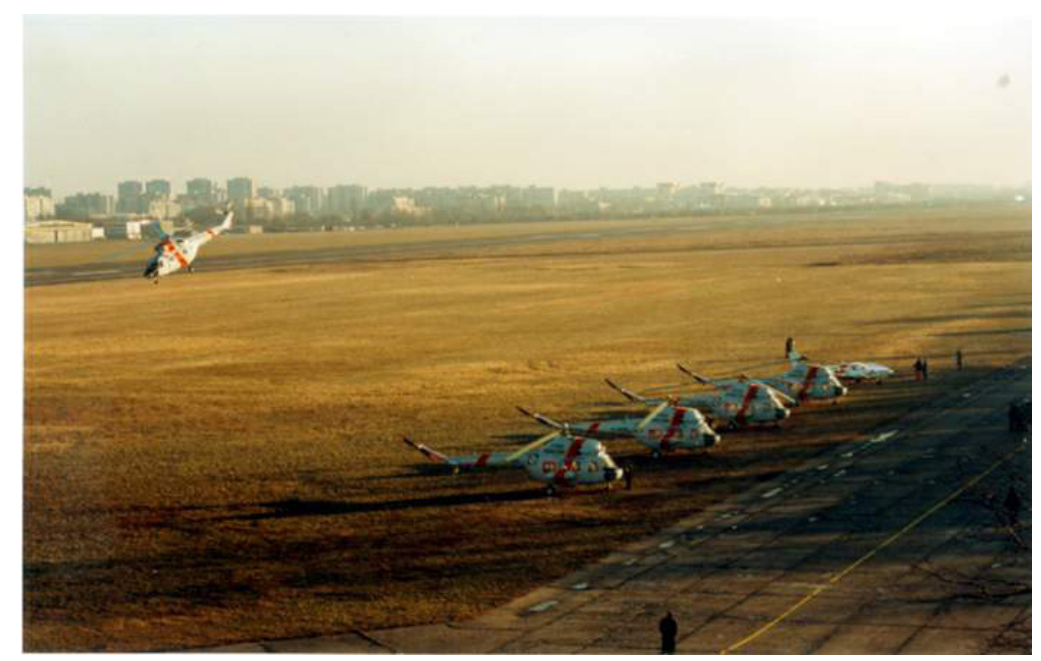

Fig. 6: The ceremony during which four Mi-2 helicopters were handed over to the Boarder Guard. It was held on 21 December 2000 at the Warszawa-Babice airfield. Image: Paweł Kłosiński.

In the summer and fall of 2000 the equipment previously flown by the military was adapted to the requirements of civil aviation. The personnel of $103 \mathrm{pl} \mathrm{NJW} \mathrm{MSWiA} \mathrm{handed} \mathrm{the} \mathrm{helicopters} \mathrm{over}$ to the Świdnik plant, to undergo a thorough overhaul. The machines were services in accordance with applicable civil aviation regulations. A set of civil documentation was drawn up as well, and registration marks assigned to Border Guard forces were affixed as well. Then, acceptance procedures were performed by the Border Guard air crews. The ground equipment, tools and spare part stocks were handed over as well.

The newly acquired helicopters were handed over to the relevant Border Guard branches, by the Minister of Interior and Administration, during a ceremony that took place at the Warszawa-Babice airfield on 21 December 2000. By the end of that year, the rotorcraft were ferried to their home bases. The Mi-2 helicopters were delivered to the following Border Guard Branched: Warmińsko-Mazurski, Nadbużański, Bieszczadzki and Lubuski. They were operating together with the airplanes used by those Branches [2].

However, they were unable to show their full potential in protecting the national border until installation of specialized equipment became possible. The newly installed systems included the following:

- infrared and visible light UltraForce 275 airborne observation system,

- SX-16 floodlight,

- modern VOR/LOG/GS navigation systems,

- GPS receiver,

- on-board winch.

- the observation pod of the system has two built-in cameras. One of them is a regular TV camera, while the other uses the $8-9$ micron infrared bandwidth. The thermal imaging camera (IF) uses the QWTP (photometric infrared measurement) technology and is capable of providing two fields of vision. The cameras are mounted on platforms with gyroscopic stabilization systems. The helicopters in which those systems are installed, have, in rear part of the cabin, an operator station with a "SONY" monitor to which the signal from the observation pod and the laptop is fed. The computer visualizes digital maps of the terrain over which the flight is performed. The same pieces 
of equipment are also relied upon to visualize the signal from the GPS system. Furthermore, the operator station is equipped with a console to control the movement of the observation pod and of the floodlight. A radio console is present as well, enabling the operator to communicate with other crew members and with the ground. The cockpit has an 8-inch monitor displaying the same information as is available to the system's operator.

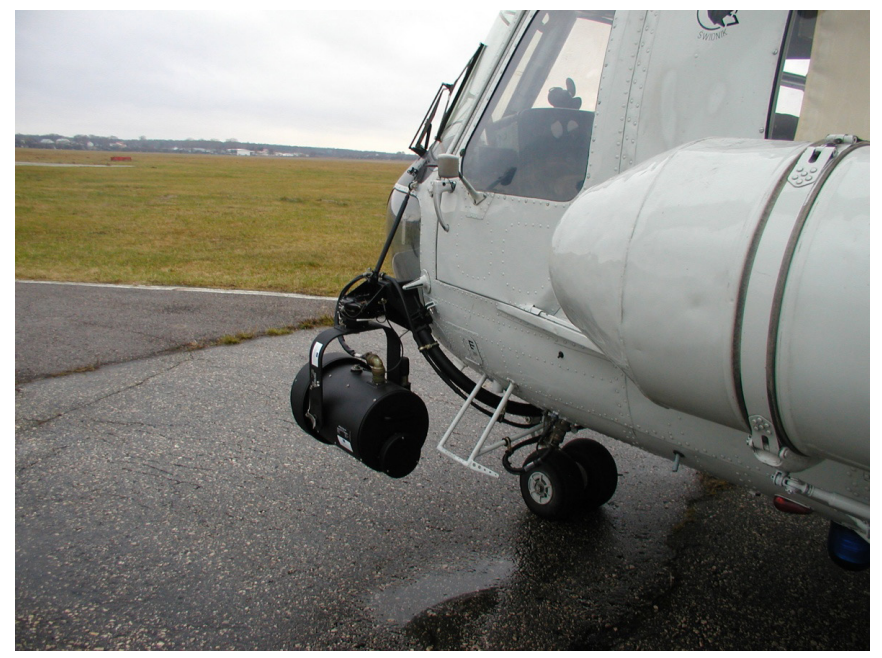

Fig. 7: SX-16 floodlight mounted on the Mi-2 helicopter. From the author's file.
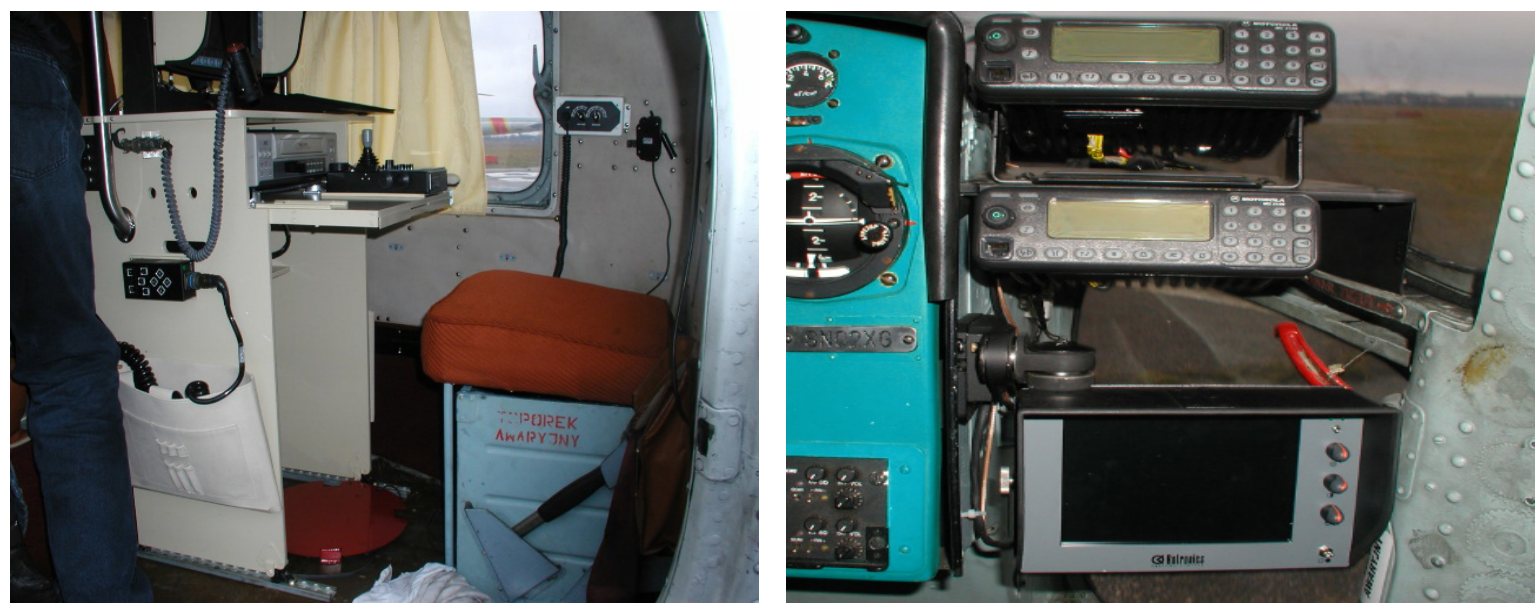

Fig. 8: left - station of the UltraForce 275 in-flight observation system operator; right - system's monitor used by the pilot, located under on-board radios. From the author's file.

\section{TASKS PERFORMED BY MI-2 HELICOPTERS}

Mi-2 helicopters made it possible to perform a wide array of tasks that are usually the domain of aircraft working in the border zone:

- patrolling the border road and adjacent areas; 
- patrolling and examining the situation on the roads leading to border crossings, detecting potential threats;

- searching for and identifying detected objects (vehicles, people);

- chasing people crossing the national border in violation of applicable regulations;

- transporting personnel to the location where the chase is to be begin, as well as offering close air support (observation and guidance);

- overseeing the activities and coordinating them from air, as well as gathering data about sites that are difficult to access;

- detecting and identifying aircraft flying at low-altitudes;

- detecting contamination of water bodies within the border zone and coordinating decontamination efforts is required;

- training own staff or personnel of other services in operating with the use of aircraft;

- participating in search and rescue missions, both within the border zone and throughout the entire country;

- participating in basic and expert training of own flying personnel;

- performing other tasks related to ensuring the internal security of the state and to protecting its resources.

The Border Guard aircraft, including Mi-2 helicopters, were also performing an extended range of tasks. These included the following:

- protecting and monitoring major transportation routes;

- participating in rescue missions after natural disasters (floods, fires, etc.);

- supporting the police force and other internal security authorities;

- transporting VIPs;

- participating in medical transport missions (mainly victims of car accidents);

- serving as a means of transport during anti-terrorist missions conducted by other services;

- performing other tasks for the benefit of central and local administration, as well as of the national economy.

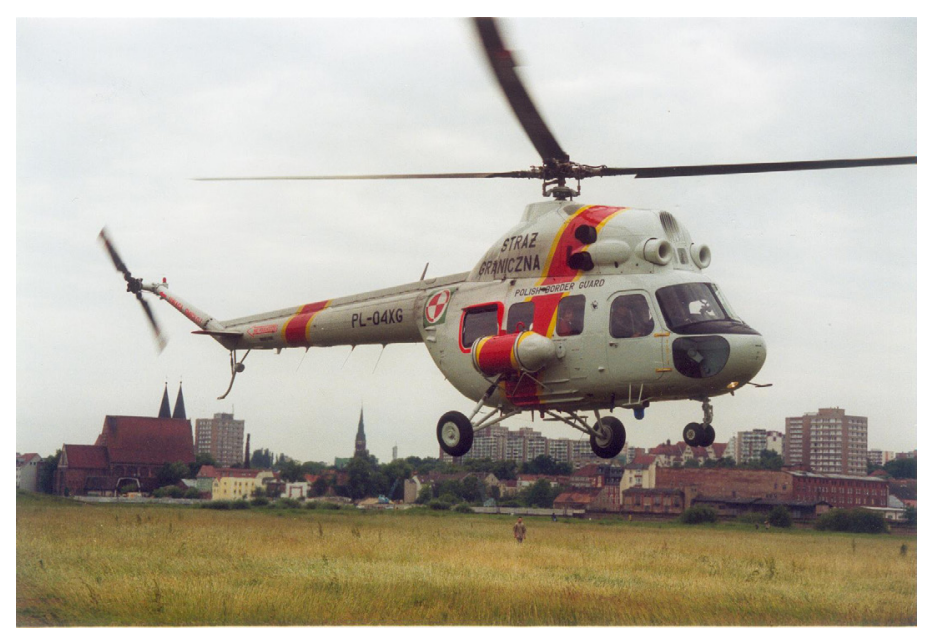

Fig. 9: Mi-2 helicopter operating in the state border zone; no airborne observation system installed yet. Image: Grzegorz Hołdanowicz. 
All tasks referred to above required that the following types of missions be performed:

- patrol,

- search,

- chase,

- search and rescue,

- transport.

The tasks performed by the Border Guard's aviation detachment can be divided into three groups:

- reconnaissance and observation,

- transporting people and resources participating in the mission,

- searching for people and objects (vehicles, goods, etc.) $[2,8,9]$.

\section{BEGINNINGS OF THE POLICE AVIATION DETACHMENT}

Helicopters have been used for policing operations since 1965, when two Mi-4 and two SM-1 rotorcraft from the Aviation Transport and Communications Squadron of the Ministry of Interior were scrambled to participate in a search for fugitives who escaped from a prison near Krosno. Special leaflets containing a message from the militia forces were dropped along the route that the fugitives were expected to have taken.

After the squadron was transformed into the 103rd Aviation Regiment of Nadwiślańskie Military Units of the Ministry of Interior (103 pl NJW MSW), it has been supplied, over the years with additional Mi-2, M-8, Mi-17, PZL W-3 “Sokół” and Bell 206B Jet Ranger III helicopters, which has enabled it to considerably expand the range of tasks performed for the benefit of the Ministry of Interior. Until 1995, $103 \mathrm{pl}$ NJW MSW was the only organizational unit offering airborne assistance to the Ministry's forces, simultaneously providing support for the police [1].

The beginning of the Polish police aviation force date back to 1996, when two first Police Aviation Teams, equipped with 2 PZL "Kania" helicopters, were established at the Voivodship Police Headquarters in Kraków and Poznań. The machines originated from the same group of rotorcraft that were used by the Border Guard [10-12]. After 103 pl NJW MSW was liquidated in 2000, its 11 helicopters were modernized and entered service as part of the Police Aviation Force that ceremonially initiated its operation on 9 May 2001. 4 of the Mi-2 helicopters were only beginning their service in the Police force.

\section{BASES OF MI-2 HELICOPTERS AND THEIR TASKS WITHIN THE POLICE FORCE}

The individual organizational units of the Police Aviation Force were based at civil airfields, located at the towns and cities identified below. They had, at their disposal (at the end of 2000), the following helicopters $[13,14]$ :

- Warsaw - Babice aerodrome, Police Aviation Headquarters, Prevention Service Office, National Police Headquarters: Three Mi-8 helicopters, one PZL W-3 “Sokół” helicopter, two Bell 206B Jet Ranger III helicopters;

- Białystok - Krywlany aerodrome, Police Aviation Department, Voivodship Police Headquarters in Białystok: One Mi-2 helicopter; 
- Gdańsk - Rębiechowo aerodrome, Police Aviation Department, Voivodship Police Headquarters in Gdańsk: One W-3 helicopter;

- Kraków - Balice aerodrome, Police Aviation Department, Voivodship Police Headquarters in Kraków: One PZL "Kania" helicopter;

- Łódź - Lublinek aerodrome, Police Aviation Department, Voivodship Police Headquarters in Łódź: One Mi-2 helicopter;

- Poznań - Ławica aerodrome, Police Aviation Department, Voivodship Police Headquarters in Poznań: One PZL "Kania" helicopter;

- Rzeszów - Jasionka aerodrome, Police Aviation Department, Voivodship Police Headquarters in Rzeszów: One Mi-2 helicopter;

- Szczecin - Dąbie aerodrome, Police Aviation Department, Voivodship Police Headquarters in Szczecin: One Mi-2 helicopter;

- Wrocław - Strachowice aerodrome, Police Aviation Department, Voivodship Police Headquarters in Wrockaw: One Mi-2 helicopter;

Over the subsequent years, the locations of Police Aviation Force bases, and well as the numbers of helicopter they were using, were changing considerably. This stemmed from the changes introduced to the operational strategy of the Police Aviation Force and of other units subordinated to the Ministry of Interior and Administration. Those changes affected, to the greatest degree, the Border Guard Aviation Detachment. The general concept assumed that the Border Guard would take over all air-support tasks so far performed in the border zones by the Ministry of Interior. This meant the Police Aviation Force bases located in Gdańsk. Białystok and Rzeszów had to be done away with.

The activity of the Police Aviation Force focuses on five major areas:

- chasing operations,

- traffic surveillance operations,

- participation in various missions requiring the use of infrared and television equipment to broadcast images to the central command post,

- training and honing the skills of anti-terrorist forces,

- cooperating with other types of aviation forces.

The detailed tasks of the Police Aviation Force include the following:

Preventive missions:

- chasing suspects and assisting in blocking escape routes,

- searching for corpses with the use of thermal imaging equipment,

- participating in policing operations aiming to ensure that public order is maintained during mass events characterized by an elevated risk level, as well as during high-level national and church celebrations, as well as during VIP visits,

- participating in rescue missions after natural disasters - providing assistance to victims located in areas that are difficult to access by land (use of ropes and winches to transport the victims to a safe location),

- participating in firefighting and fire prevention missions (identifying fire threats to forests, informing about fires detected),

- ensuring that order is maintained on water bodies, and participating in rescue missions,

- cooperating with traffic police forces operating on the country's main roads, and coordinating their activity with other police forces, 
- monitoring all high-value transports and transport of works of art for which government guarantees have been issued.

Counteracting regular and economic crimes:

- observing areas that are particularly prone to common and organized crime, providing support (including of medical nature) for on-ground missions,

- providing quick transport for police investigators, miners and explosive technicians, crime scene technicians, negotiators, anti-terrorist forces,

- participating in police missions conducted by the criminal department - searching for missing persons, fugitives, those under arrest, prison escapees, as well as for other people of interest for the Police,

- preventing and counteracting crime along major transportation routes,

- cooperating with commercial entities in tasks involving protection of people and property, and in recovering stolen vehicles,

- monitoring the whereabouts of fugitives (photographic and video documentation of routes leading from locations at which ransom was collected to the places at which hostages were held),

- observing water bodies, detecting crimes and offenses, as well as directing boat patrols to specific locations,

- detecting stolen loads, temporary warehouses and other facilities connected to criminal activity and located in inaccessible areas (mountains, forests, marshes),

- detecting theft of fuel from pipelines, storage facilities, theft of railway and power grid elements,

- detecting illegal alcohol production facilities in wetlands (where they are usually located), as well as transporting sappers to the location to liquidate the production facilities,

- observing forests and water bodies to counteract poaching and illegal tree felling,

- detecting illegal poppy and cannabis plantations, etc.

- cooperating with the criminal police department and with the Border Guard to counteract crime involving illegal trade in money, weapons, ammunition and drugs,

- cooperating with the Border Guard to protect the integrity of the state border,

- combat training and real combat operations with anti-terrorist forces,

- performing executive and transport flights with police mission and operation commanders,

- cooperating with the police forces from neighboring countries $[13,14]$.

Despite the fact that helicopters used by the Police did not have any specialized equipment (with the exception of police radios and a strobe light), they were capable of performing nearly all tasks referred to above. In 2008 and 2009, when the public order services were reorganized, $3 \mathrm{Mi}-2$ helicopters with additional equipment (Fig. 11) were handed over from the Border Guard to the Police. Today, they still remain in active service, along with other aircraft owned by the Police force. They continue to provide air support for police operations, although their parameters are inferior to those of the Kania or the Bell. 


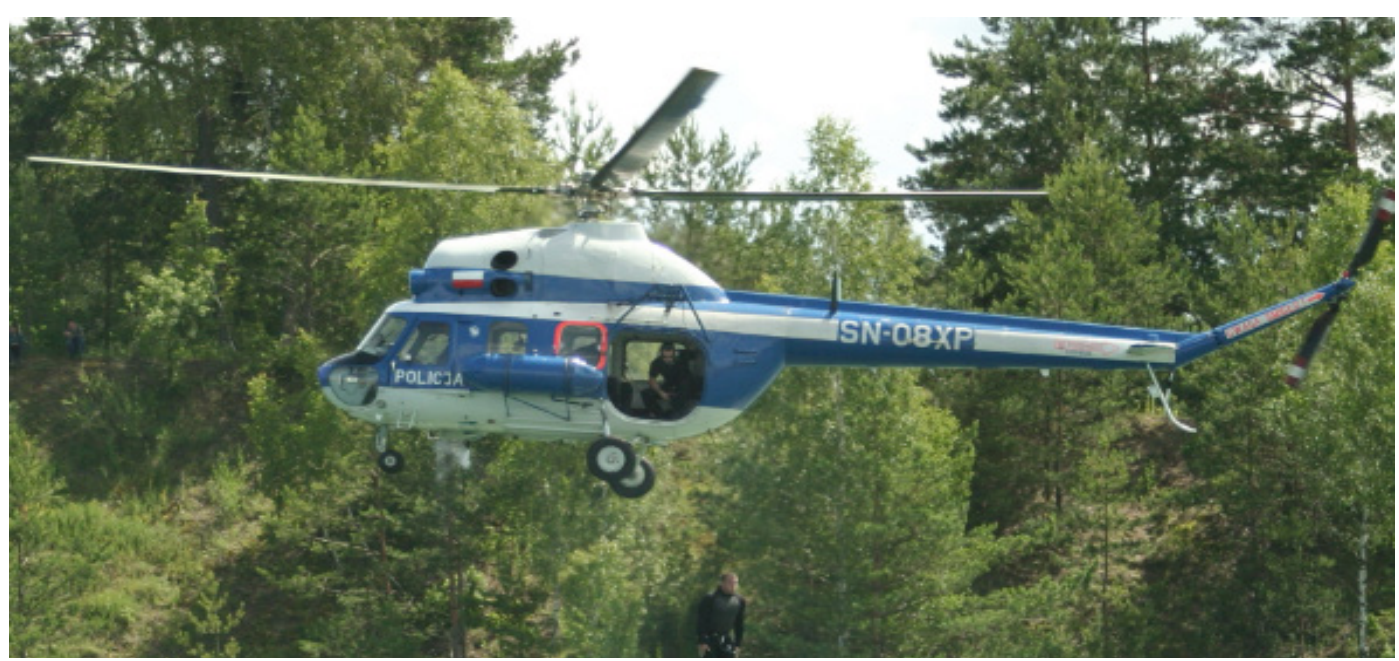

Fig. 10: A Mi-2 helicopter used during water rescue missions conducted by the police. Image: Paweł Kłosiński.

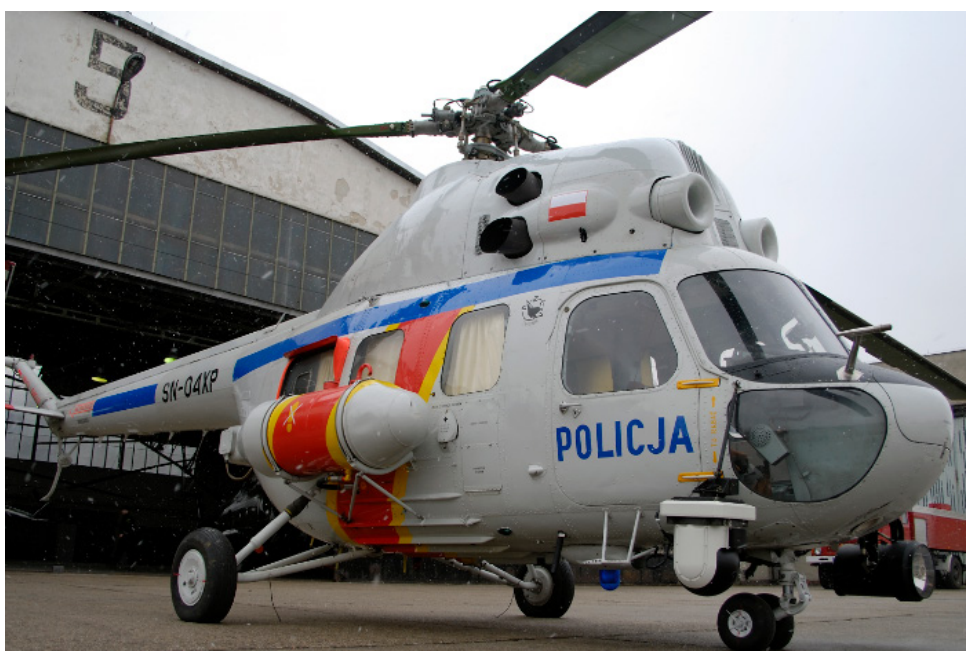

Fig. 11: Mi-2 helicopter handed over by the Border Guard to the Police. Instead of being removed, the Border Guard livery was only covered with the Police livery. Image: Paweł Kłosiński.

\section{SUMMARY}

As described above, Mi-2 helicopters have played a key role in the performance of the tasks that individual organizational units of the Ministry of Interior have been entrusted with. They served as the working horse of the force, and continue to be used by the Police (formerly militia) and the Border Guard (formerly Border Protection Forces) while performing their statutory duties. Thanks to their inherent characteristics, Mi-2 could be easily adapted to the tasks they were expected to cope with. They have also proved to be reliable, and relatively easy to operate and maintain. The fact that this type of rotorcraft has been in service for 50 years now, is a clear indication of its reliability and versatility. 


\section{BIBLIOGRAPHY}

[1] $103^{\text {rd }}$ Regiment of the Vistula Military Units at the Ministry of the Interior and Administration, a folder, (in Polish: Folder - 103 Pułk Lotnictwa Nadwiślańskich Jednostek Wojskowych Ministerstwa Spraw Wewnętrznych), 1994, CIS, Warsaw.

[2] Konieczka R., 2011, "Border Guard Aviation. Border Guard in years 1991-2011". Post-seminar papers, vol. II, (in Polish: Lotnictwo Straży Granicznej. Straż Graniczna w dwudziestoleciu 19912011, Centralny Ośrodek Szkolenia Straży Granicznej), The National Centre For Border Guard Training, Koszalin.

[3] $103^{\text {rd }}$ Regiment of the Vistula Military Units at the Ministry of the Interior and Administration, 70 Years, a folder, (in Polish: Folder - 103 Pułk Lotnictwa Nadwiślańskich Jednostek Wojskowych Ministerstwa Spraw Wewnętrznych, 70 lat), 2014, Warszawa.

[4] Hołdanowicz G., 1997, "Protecting the Borders and the State", (in Polish: W ochronie granic i państwa), Skrzydlata Polska, No. 2.

[5] Disposition No. 020 of the Border Guard Commander-in-Chief of 29 April 1995, (in Polish: Zarządzenie nr 020 Komendanta Głównego Straży Granicznej z dnia 29 kwietnia 1995 r.).

[6] Konieczka R., 2000, "Aircraft in Border Protection". Materials from the "Border Guard - Future - Directions - Solutions” Symposium, Borders Guard Publishing House, (in Polish: Statki powietrzne w ochronie granicy państwowej, Materiały z sympozjum „Straż Graniczna - przyszłość - kierunki - rozwiązania”), Wydawnictwo Straży Granicznej, Kielce.

[7] Konieczka R., 2000, "A Helicopter or an Airplane? Basic Principles Behind Selecting a Proper Aircraft For Various Task in Border Protection. Questions of Border Protection”, (in Polish: Śmigłowiec czy samolot. Podstawowe aspekty wyboru rodzaju statku powietrznego do realizacji zadań w ochronie granic, Problemy ochrony granic. Biuletyn Centrum Szkolenia Straży Granicznej, No. 14, Kętrzyn.

[8] Konieczka R., 2000, "The Use of Aircraft by Border Protection Agencies". Aviation Institute Works 160, 3rd national Rotorcraft Forum, (in Polish: Zastosowanie statków powietrznych w służbach granicznych), Transactions of the Institute of Aviation, No. 1(160).

[9] Kłosiński P., 2001, „Over a Dam”, (in Polish: Nad zapora), Skrzydlata Polska, No. 7.

[10] Hołdanowicz G., 1996, "Aviation of No Man's Zones" (in Polish: Lotnictwo strefy niczyjej), Skrzydlata Polska, No. 8.

[11] Hołdanowicz G., 1995, "Dance with Sabers”, (in Polish: Taniec z szablami), Skrzydlata Polska, No. 11.

[12] Jaxa-Małachowski R., Hołdanowicz G., 1997, "The French Model” (in Polish: Model Francuski), Skrzydlata Polska, No. 2.

[13] Frątczak D., 2003, The Principles of Airforce Support Units Operation within Polish Police Structures. 5th Rotorcraft Forum. (in Polish: Zasady funkcjonowania jednostek wsparcia lotniczego w strukturach polskiej Policji, V Forum Wiropłatowe), Aviation Institute, Warsaw.

[14] Frątczak D., 2008, “The Principles of Operation and Tasks of the Police Aviation”, 100 Years of Rotorcrafts (in Polish: Zasady funkcjonowania i zadania Lotnictwa Policji, Stulecie lotnictwa Śmigłowcowego), Transactions of the Institute of Aviation, No. 194-195.

\section{BIBLIOGRAPHY - APPENDICES}

[1] Borgoń J., Konieczka R. i Stankiewicz Z., 2008, ”A Moldel Helicopter for Land Border Portection", (in Polish: Modelowy śmigłowiec do wykonywania zadań w ochronie granicy państwowej nad lądem), Transactions of the Institute of Aviation, No. 194-195. 
[2] Kłosiński P., 1999, "Safely and under Law", (in Polish: Zgodnie z prawem i bezpiecznie), Skrzydlata Polska, No. 11.

[3] Konieczka R., 2010, "Border Guard Aircraft Insignia", Newsletter of The National Centre For Border Guard Training, (in Polish: Oznakowanie statków powietrznych Lotnictwa Straży Granicznej, Biuletyn Centralnego Ośrodka Szkolenia Straży Granicznej, nr 4), Koszalin.

[4] Konieczka R., 2009, "The Beginnings of Aircraft Use in Polish Border Protection in the Outline of the History of the Independent Reconnaissance Air Squadron at the Border Protection Forces", Newsletter of The National Centre For Border Guard Training, (in Polish: Początki wykorzystania lotnictwa w ochronie granicy państwowej polski w zarysie dziejów Samodzielnej Eskadry Lotnictwa Rozpoznawczego Wojsk Ochrony Pogranicza, Biuletyn Centralnego Ośrodka Szkolenia Straży Granicznej, nr 2), Koszalin.

[5] Konieczka R., 2011, "The Use Of Aviation by the Border Protection Corps in Years 1936-1939", Newsletter of The National Centre For Border Guard Training, (in Polish: Wykorzystanie Lotnictwa w Korpusie Ochrony Pogranicza w latach 1936-1939, Biuletyn Centralnego Ośrodka Szkolenia Straży Granicznej, nr 1), Koszalin.

[6] Konieczka R., 2014, "Aviation Border Guard Colour Code", (in Polish: Barwy Lotnictwa Straży Granicznej), Aeroplan, No. 4.

[7] Zabłocki E., 2008, "Civil Aviation, Law Enforcement Agencies Aviation", (in Polish: Lotnictwo cywilne, Lotnictwo służb porządku publicznego), National Defence University, Warsaw.

[1] Aviation Law Act dated 3 July 2002, Journal of Laws No. 130 item 1112 of 16.08.2002, (in Polish: Ustawa Prawo lotnicze z 3 lipca 2002 roku) (Dz.U. Nr 130 poz. 1112 z dnia 16.08 .2002 roku).

[2] Police Act dated 6 April 1990, Journal of Laws 2007.43.277, (in Polish: Ustawa z dnia 6 kwietnia 1990 r. o Policji) (Dz.U.2007.43.277).

[3] Border Guard Act dated 12 October 1990, Journal of Laws 2005.234.1997, (in Polish: Ustawa z dnia 12 października 1990 r. o Straży Granicznej) (Dz.U.2005.234.1997).

[4] Disposition No. 17 of the National Police Commander, dated 18 July 1995, (in Polish: Zarządzenie nr 17 Komendanta Głównego Policji z dnia 18 lipca 1995 roku).

[5] Disposition No. 54 of the National Border Guard Commander, dated 15 November 2002 - Operating Instructions for the Border Guard Aviation Service, (in Polish: Zarządzenie Nr 54 Komendanta Głównego Straży Granicznej z dnia 15 listopada 2002 - Instrukcja Operacyjna Lotnictwa Straży Granicznej).

[6] Disposition No. 31 of the President of the Council of Ministers, dated 25 March 2008 on the Statute of the Ministry of Interior and Administration, Official Journal 2008.25.247, (in Polish: Zarządzenie Nr 31 Prezesa Rady Ministrów z dnia 25 marca 2008 r. w sprawie nadania statutu Ministerstwu Spraw Wewnętrznych i Administracji) (M.P.2008.25.247).

[7] Communiqué by the Minister of Interior and Administration dated 16 September 2008 on the list of organizational units subordinated to the Minister of Interior and Administration or supervised thereby, Official Journal 2008.77.691, (in Polish: Obwieszczenie Ministra Spraw Wewnętrznych i Administracji z dnia 16 września 2008 r. w sprawie wykazu jednostek organizacyjnych podległych Ministrowi Spraw Wewnętrznych i Administracji lub przez niego nadzorowanych) (M.P.2008.77.691).

[8] Regulation of the President of the Council of Ministers dated 16 November 2007 on the detailed scope of activity of the Minister of Interior and Administration, dated 16 November 2007, Journal of Laws 2007.216.1604, (in Polish: Rozporządzenie Prezesa Rady Ministrów z dnia 
16 listopada 2007 r. w sprawie szczegółowego zakresu działania Ministra Spraw wewnętrznych i Administracji) (Dz.U.2007.216.1604).

[9] Disposition No. 31 of the President of the Council of Ministers, dated 25 March 2008 on the Statute of the Ministry of Interior and Administration, Official Journal 2008.25.247, (in Polish: Zarządzenie Nr 31 Prezesa Rady Ministrów z dnia 25 marca 2008 r. w sprawie nadania statutu Ministerstwu Spraw wewnętrznych i Administracji) (M.P.2008.25.247).

[10] Agreement between the Minister of Interior and the Minister of Transport and Maritime Economy on the establishment and operation of a public service aviation force within the Ministry of Interior, dated 22 May 1996, (in Polish: Porozumienie pomiędzy Ministrem Spraw Wewnętrznych oraz Ministrem Komunikacji i Gospodarki Morskiej w sprawie powołania i zasad działania lotnictwa służb porządku publicznego w resorcie spraw wewnętrznych z dnia 22.05.1996 r.).

[11] Agreement between the Minister of Interior and Administration and the President of the Civil Aviation Authority, dated 24 December 2002, (in Polish: Porozumienie pomiędzy Ministrem Spraw Wewnętrznych i Administracji, a Prezesem Urzędu Lotnictwa Cywilnego z dnia 24.12.2002 r.).

\section{WYKORZYSTANIE ŚMIGŁOWCÓW MI-2 W JEDNOSTKACH ORGANIZACYJNYCH LOTNICTWA RESORTU SPRAW WEWNĘTRZNYCH}

\section{Streszczenie}

W artykule autor przedstawia szerokie wykorzystanie śmigłowców Mi-2 w różnych jednostkach podległych ministrowi spraw wewnętrznych od momentu wprowadzenia tej konstrukcji do czasów współczesnych. Ujawnia kulisy początków eksploatacji tego typu śmigłowców w latach 60-dziesiątych w strukturach 103 pułku lotnictwa NJW MSW. Przedstawia wybrane zagadnienia dotyczące wdrażania tej konstrukcji, szkolenia, metod wykorzystania i problemów użytkowych. Śmigłowce Mi-2 zakończyły swą służbę w strukturach wojsk resortu spraw wewnętrznych w chwili ich likwidacji. Tym samym rozpoczął się kolejny rozdział ich szerokiego wykorzystania w strukturach Policji i Straży Granicznej, gdzie do dziś dnia kończą swój resurs. W opracowaniu przedstawiono realia wykonywania specyficznych zadań, lokalizacje baz lotniczych, zmianę filozofii wykorzystania tych śmigłowców; ich wady i zalety. Jednocześnie wskazano śmigłowiec PZL-Kania jako unowocześnioną modyfikację Mi-2 wykorzystywaną w Polsce jedynie w formacjach lotniczych jednostek MSWiA.

Słowa kluczowe: Ministerstwo Spraw Wewnętrznych i Administracji, śmigłowiec Mi-2, bezpieczeństwo publiczne, Nadwiślańskie Jednostki Wojskowe, Straż Graniczna, Policja. 